\title{
Discrimination in the hiring of older jobseekers: Combining a survey experiment with a natural experiment in Switzerland
}

\author{
Daniel Oesch \\ Life Course and Inequality Research Centre (LINES), LIVES - Swiss National Centre of Competence in Research, University of Lausanne, 1015 Lausanne, Switzerland
}

\section{A R T I C L E I N F O}

\section{Keywords:}

Age discrimination

Hiring

Survey experiment

Natural experiment

Unemployment

Switzerland

Late careers

Job displacement

Older workers

Wages

\begin{abstract}
A B S T R A C T
Older workers who lose their job are at great risk of experiencing long-term unemployment. This vulnerability can be due to negative selection into unemployment or to age discrimination by employers. We empirically test three explanations of why older jobseekers may struggle to get reemployed: employers promote internal careers; employers prefer younger workers for physically demanding jobs; employers perceive older workers as being too expensive. We test these hypotheses by analysing two experiments in Switzerland. In a factorial survey experiment, 500 recruiters indicated for fictional CVs with ages 35-55 the likelihood of an invitation to a job interview. In a natural experiment, 1200 workers were surveyed two years after their plant closed down, allowing us to compare age gaps in reemployment among workers displaced by the same exogenous event. Combining the two experimental methods allows us to increase internal and external validity. Both the factorial survey among recruiters and the survey among displaced workers show large age barriers in hiring. Unemployed workers aged 55 are much less likely to be considered for hiring than those aged 35 with the same productive attributes. This age penalty is larger for blue-collar workers and clerks than upper-level white-collar employees, throwing doubt on the internal career hypothesis. By contrast, results for earnings are consistent with the argument that older workers' reemployment chances are hampered by high wage costs.
\end{abstract}

\section{Introduction}

Over the last two decades, governments across Europe have increased the statutory retirement age. Postponing the pension age means that older workers depend on labour market income for longer periods of their lives. These policy changes take place against a background where older jobseekers struggle to find reemployment and face much longer unemployment spells than younger jobseekers in both Europe and the US (Farber, Silverman, \& Von Wachter, 2017: 169). Such agerelated barriers in hiring seem at odds with government exhortations to work longer.

At the same time, the unemployment rates of older workers lie systematically below those of younger age groups across the OECD. Unemployment among older workers is then defined less by the risk of becoming unemployed than by the vulnerability of remaining unemployed for long periods of time (Hornstein \& Lubik, 2015: 135). Unemployment may thus have a heterogeneous effect on age groups, leaving deeper scars on older than mid-aged and young individuals (Gangl, 2006).

In recent years, the issue of causal heterogeneity has attracted growing interest among social stratification researchers (e. g. Brand \& Xie, 2010; Xie, Brand, \& Jann, 2012). The idea is that the same treatment (say, unemployment) affects different population groups (say, age cohorts) in different ways. At the same time, effects that are actually homogeneous (and thus do not differ between age groups) may easily be mistaken as being heterogeneous if unobserved selection has an influence on both the treatment (such as losing one's job) and outcome (such as getting reemployed) (Breen, Choi, \& Holm, 2015).

This argument is relevant because unobserved selection into unemployment is likely to be stronger among older than younger workers. When young workers enter the labour market, they typically experience periods of unemployment and job-hopping before finding a good employer match. Since most new jobs are unstable and of short duration, spells of unemployment are more common at earlier than later stages of the work career (Farber, 1999: 16; Hornstein \& Lubik, 2015: 135). The fewer old workers who become unemployed may thus be selected more negatively. This argument would thus explain older jobseekers' reemployment difficulties by their (unobserved) work-related characteristics rather than by their age.

Yet there are also good reasons to expect a truly heterogeneous effect of age on reemployment. This is the case if employers hold agerelated stereotypes and avoid hiring older workers because they consider them to be less resistant to stress, less competent in new technologies, to make higher wage demands or to be less productive overall

E-mail address: daniel.oesch@unil.ch. 
than younger workers (Karpinska, Henkens, \& Schippers, 2013).

Our paper analyses the extent and causes of age barriers in hiring discrimination against older jobseekers - on the basis of two experiments. We first turn to a factorial survey experiment (also known as vignette study) where $500 \mathrm{HR}$ professionals indicate the likelihood that they would invite fictional jobseekers to a job interview. By randomly varying a set of dimensions in the résumés, we are able to see whether unemployed workers aged 50 or 55 are less likely to get a job interview than their colleagues aged 35 or 40 . Second, we use mass displacement as a natural experiment and surveyed 1200 workers two years after their plant closed down. This survey allows us to compare age differences in reemployment rates among jobseekers who were made redundant by the same exogenous event.

The two experiments complement each other. The factorial survey informs us of the demand-side of the labour market - employers and their ratings - and has strong internal validity. Yet although we targeted actual recruiters rather than undergraduate students or random individuals, the factorial survey only captures hiring intentions in a hypothetical setting. For this reason, we combine the vignette study with a mass displacement survey, which focuses on the supply-side of the labour market - jobseekers and their reemployment chances - and reflects real-life behaviour, thus providing us with stronger external validity.

All our data for the vignette study and mass displacement survey were collected in Switzerland. Evidence from the United States (Farber et al., 2017) and the Netherlands (Karpinska, Henkens, \& Schippers, 2011) suggests that employers discriminate less against older workers when the labour market is tight. The Swiss labour market has been marked by labour shortage over much of the last decades, as is illustrated by low unemployment rates and large inflows of work migrants (Murphy \& Oesch, 2018). If labour shortage makes discrimination costly (Baert, 2018), it should be particularly hard to find evidence for discrimination in Switzerland.

Our study is structured as follows. Section 2 develops the theoretical hypotheses of why employers may shy away from hiring older jobseekers. Section 3 provides a review of findings on age discrimination in field, laboratory and natural experiments. Sections 4 and 5 present our factorial survey experiment, the mass displacement survey and discusses the institutional context. Section 6 shows the results, revealing in both datasets a large gap in employment probabilities between young and older jobseekers. Section 7 summarizes our findings and discusses their policy implications.

\section{Why would employers discriminate against older workers?}

The literature on age discrimination highlights the paradox that while most employers have older workers under employment, they refrain from newly hiring older workers. Schematically, three sets of reasons may account for employers' reluctance to recruit older jobseekers.

First and foremost are worries about job performance and the widespread expectation that older workers are less productive because of lower physical strength, health issues, outdated IT-skills, a lack of fluency in foreign languages or little motivation for further education (Homrighausen \& Wolf, 2018: 3). These beliefs about the characteristics of individuals in different age groups are widely shared across Western Europe (Radl, 2012) and thus represent powerful age stereotypes (Rosen \& Jerdee, 1976: 180). Another question is whether they also amount to discrimination, defined as a situation where jobseekers with the same productive abilities are treated differently based on their nonproductive characteristics (Büsch, Dahl, \& Dittrich, 2009: 41). This depends on whether age is systematically linked to productivity, making workers in their mid-fifties less productive than workers in their mid-thirties.

Overall, the literature suggests that age is a weak indicator of a jobseeker's mental and physical abilities and thus a poor predictor of his or her work performance. A large meta-analysis reports a null relationship between age and ten core dimensions of job performance $\mathrm{Ng}$ \& Feldman, 2008: 403). Similarly, a review of over 100 studies concludes that there is no significant difference in work productivity between older and younger employees (Warr, 1995: 309). Variance in work productivity is likely to be much larger within an age category than between age categories. Nonetheless, an overview article argues that worker productivity increases during the initial years in the labour market before stabilizing and often declining towards the end of the working life. This decline concerns job tasks where speed and endurance are important, but not tasks where experience and verbal abilities matter more (Skirbekk, 2008: 4).

If employers' reluctance to hire older workers is motivated by doubts about their physical performance, the age penalty should be stronger in occupations requiring speed and endurance than in occupations demanding long experience and specialized expertise. Bluecollar workers such as assemblers and building caretakers stand for the former, high-level managers and professionals for the latter, the best example being legislators whose name "senator" (from Latin senex meaning "old") suggests a job reserved for elder citizens. This leads us to formulate a first hypothesis.

Hypothesis 1. If employers expect older workers to underperform in tasks requiring speed and endurance, the age barrier in hiring should be larger in blue-collar occupations than in occupations held by professionals and managers, with office clerks in an intermediate position.

Second, the hiring of older workers may contradict the logic of longterm employment relationships where firms motivate younger workers to stay on with a deferred compensation scheme based on seniority. In this setting, the recruitment of older candidates interferes with implicit promises made to younger employees because it runs contrary to the policy of primarily promoting internal careers (Daniel \& Heywood, 2007: 36-7). Related to this argument is the idea that investing in the training of new workers may not be profitable if these workers have only a few more years to go until retirement.

This argument has clear implications for how the age penalty should vary across occupations. If employers restrain from hiring older workers because their organization uses long-term incentive schemes and promotes internal careers, the age barrier should be higher for managers and professionals than office clerks and blue-collar workers who rarely benefit from internal labour markets. Likewise, investing in the training of managers and professionals should be more costly than preparing an office clerk or a blue-collar worker for his or her new job. This leads to our second hypothesis.

Hypothesis 2. If the age barrier is caused by employers' concern about internal careers, the age penalty should be larger for managers and professionals than office clerks and blue-collar workers who largely operate outside of internal labour markets.

Third, older jobseekers may face difficulties to find a new job because they are expected to be too costly in terms of wages. The idea is that older workers possess valuable experience and expertise, but these skills come to a large extent with increased firm-tenure and cannot be transferred easily to another organization. When made redundant, older workers may therefore lose their firm-specific productivity advantage relative to younger workers. To the extent that prospective employers expect older workers to demand wages similar to those earned before redundancy, older jobseekers may not be hired because their wages exceed their productivity (Lassus, Lopez, \& Roscigno, 2015: 85). Expressed differently, this hypothesis implies that if displaced older workers are no more productive than younger workers, but their wages were higher, older jobseekers will only get reemployed if they accept to earn substantially less. This expectation is spelled out in our third hypothesis.

Hypothesis 3. If the age barrier in hiring is due to employers' expectation 
that older workers cost too much relative to their productivity, employers will not hire older jobseekers unless these latter put up with large wage cuts.

\section{Earlier evidence on age discrimination in hiring}

Observational studies based on regressions typically find that older jobseekers face higher entry barriers to the labour market than younger jobseekers (e.g. Hirsch, Macpherson, \& Hardy, 2000). However, unemployment spells are less frequent among older than younger workers and thus concern a smaller and possibly more negatively selected group. This has led social scientists to increasingly challenge the conclusions of labour market discrimination based on non-experimental research (see Neumark, 2018: 800). If older workers with health problems are made redundant, their struggle to become reemployed may be due to unobserved characteristics (such as failing health) and not employers' preference for younger workers per se. This growing awareness of unobserved heterogeneity has turned experiments into the gold standard in research on hiring discrimination, notably field experiments, laboratory experiments and natural experiments.

Field experiments on age discrimination mainly consist of correspondence studies where researchers send applications of fictitious jobseekers to real employers. These jobseekers are identical in all productivity-related features and solely vary in their age. Two review articles on correspondence testing find that age discrimination exists in basically all the countries studied and is sizeable. Notably, age discrimination in call-back rates appears to be larger than discrimination based on ethnicity, gender or sexual orientation (Baert, Norga, Thuy, \& Van Hecke, 2016: 89; Neumark, 2018). In correspondence studies for Britain, France, Germany and Spain, call-back rates are consistently lower for older than younger waiters (Riach, 2015). Likewise, Farber et al. (2017: 172) show for the United States that unemployed office clerks in their fifties are significantly less likely to be called back than those in their thirties and early forties. While there is no difference in the call-back rates for applicants aged 35-37 and 40-42, the call-back rate drops markedly for ages 55-58 (Farber et al., 2017: 180).

Most correspondence studies use large entry-level occupations such as sales assistants or waiters, with office clerks as a common alternative (see the overview by Baert et al., 2016: 89). The literature finds substantial age barriers for all these jobs and throws doubt on the argument that age discrimination is solely due to internal labour markets: Most waiters and sales assistants do not evolve in internal labour markets (see Farber et al., 2017; Riach, 2015). Likewise, age discrimination does not seem to be restricted to occupations with direct customer contact (Lahey, 2008) and does not vary much between administrative assistants, vendors, security guards or building caretakers (Neumark, Burn, \& Button, 2015: 45). At the same time, none of these studies explicitly tests differences in age discrimination between occupations.

The most common laboratory experiment uses vignette studies. One of the earliest vignette studies on age discrimination surveyed 50 students and 56 real estate agents in the US and found that 60 -year old workers were rated systematically lower on performance capacity than 30-year old workers (Rosen \& Jerdee, 1976). In a replication study, Weiss and Maurer (2004) found little evidence of age discrimination for a sample of 204 undergraduate students in the United States. By contrast, Büsch et al. (2009) find age discrimination in hiring for a student sample and a small group of personnel managers in Germany, but not in Norway. In the Netherlands, several factorial survey experiments analyse the circumstances in which retired jobseekers are re-hired (Karpinska et al., 2011; Mulders, van Dalen, Henkens, \& Schippers, 2014) or older workers are kept on rather than offered early retirement (Henkens, van Solinge, \& Cozijnsen, 2009; Karpinska et al., 2013). These studies conclude that, regardless their skill level, workers who have reached the retirement age are unlikely to be kept on or newly hired - except in tight job markets. When labour shortage looms large, the chances of older workers improve.
While basically all the published correspondence studies find age discrimination (Neumark, 2018), this is not the case for vignette studies. This discrepancy may be due either to a publication bias against null results in correspondence studies or to socially desirable answers in vignette studies. The likelihood of respondents giving socially desirable answers and denying any form of age discrimination is high if vignette studies manipulate only one single dimension, namely age - as is the case in Büsch et al. (2009), Rosen and Jerdee (1976) or Weiss and Maurer (2004).

A final set of studies uses plant closure as a natural experiment. The idea is that plant closure represents an exogenous source of variation where all workers lose their jobs irrespective of their individual performance and productive characteristics. These studies typically find that displaced older workers face the choice between reemployment with large earnings losses, involuntary early retirement or long periods of unemployment - be it in Finland (Jolkkonen, Koistinen, \& Kurvinen, 2012), Germany (Knuth \& Kalina, 2002), Switzerland (Baumann, 2016) or the USA (Chan \& Stevens, 2001). The same result is shown by a panel analysis for Germany that compares displaced and non-displaced older workers over time based on a matching technique (Heisig \& Radl, 2017).

In all these countries, the age barrier in reemployment is substantial. As a case in point, the analysis of the American Displaced Workers Survey 1994-2016 shows a larger reemployment gap after job loss between mid-aged (35-44) and older workers (55-64) than between workers with a college degree and workers having no more than high-school education. The age gap is 16 percentage points as compared to 12.5 points for the education gap, suggesting that an older age is a greater handicap for reemployment in the United States than low levels of education (Farber, 2017: 249).

\section{Data and methods}

\subsection{Factorial survey experiment}

Our analysis first examines the extent of and reasons behind age discrimination with a factorial survey experiment. By combining the logic of an experiment with that of a social survey, factorial surveys present four attractive features (Auspurg \& Hinz, 2015; McDonald, 2019; Wallander, 2009). First, they enable the researcher to create the résumés of fictitious job candidates (vignettes) who have the same productive characteristics and simply differ in terms of age (or gender or nationality). Second, the random assignment of vignettes to respondents allows the researcher to fully control the information shown to respondents and thus excludes unobserved characteristics (such as a jobseeker's motivation) that affect the outcome variable (such as hiring). Third, jobseekers' attributes such as age, gender, nationality or education vary randomly in each vignette. These ever-changing combinations make it hard for respondents to pick out the central dimension of interest, thus reducing the social desirability bias. This point has been forcefully shown by Auspurg, Hinz, and Sauer (2017) for the gender wage gap in Germany: In their factorial survey, respondents indicated systematically higher wages for male than female profiles. Finally, factorial surveys raise fewer ethical concerns than correspondence studies, where employers are intentionally misled by fictitious applications, with possibly disruptive consequences for recruitment and the running of businesses.

As a drawback, factorial surveys present hypothetical scenarios that may be seen as unrealistic and elicit little respondent engagement. Moreover, the ratings of vignettes only reflect the stated intentions of respondents, which may differ from their effective actions (Pager \& Quillian, 2005). The degree to which stated intentions can be generalized to the recruitment process is further limited if these intentions are collected among undergraduate students or the general population.

Our factorial survey tries to address this last issue by targeting real recruiters. In 2016, we sent a web-based questionnaire to around 4000 
HR managers in Switzerland and obtained responses from 537 individuals, a response rate of around 13 percent. $^{1} 93$ percent of all respondents had been actively involved in at least one recruitment over the last 12 months, the median number of recruitments being ten. Our analytical sample only includes these active recruiters. They are, on average, 46 years old and in their majority women (63 per cent female), disproportionately work in large organizations and mostly answered the survey in German (70 per cent against 30 percent in French).

Our factorial survey experiment was presented as a study of hiring practices in different industries and regions for three occupations: expert accountant, human resources assistant and building caretaker. These three occupations are common in many organizations and represent three hierarchical levels in terms of skill requirements: a highskilled professional occupation (ISCO major group 2), a mid-skilled clerical occupation (ISCO 4) and a low-skilled blue-collar occupation (ISCO 9). This allows us to test our hypotheses which expect age discrimination to vary across occupations.

Recruiters were asked to indicate for 12 vignettes (4 per occupation) first the likelihood that they would invite a candidate to a job interview (on a scale from 0 to 10) and second the monthly wage that seemed adequate for a given candidate, regardless of the likelihood of a job interview. All candidates were presented as being unemployed because their company has closed down. The order in which vignettes were presented was randomized. Taking out non-responses and using only active recruiters, we are left with 501 recruiters who provide us with their ratings for 5290 candidates. These 5290 ratings constitute our analytical sample.

The profiles of our job candidates - the vignettes - are made up of 11 dimensions, including age, gender, nationality and the type of education. Tables A1 and A2 in the Appendix A present all the vignette dimensions and levels and show an example of the vignettes. A thorny issue in experimental studies of age discrimination is the amount of work experience that different candidates should have. Our factorial survey mentions for all candidates that they have eight years of work experience in the occupation for which they applied. Thanks to randomization, all the vignette dimensions such as age, gender, or nationality are uncorrelated to each other (see Table W.1 in the web-appendix for the correlation matrix). ${ }^{2}$

\subsection{Mass displacement survey}

Due to their experimental design, factorial surveys have high internal validity. However, the extent to which findings can be generalized to other contexts is less certain. For this reason, we use a second dataset of displaced workers who were surveyed about two years after their plant had closed down. This setting comes close to a natural experiment (Brand, 2015: 361). Plant closure does not completely solve the issue of selection if the most dynamic workers decipher the writing on the wall and leave the failing firm before it goes bankrupt. Moreover, plant closure is more likely to take place in firms and sectors where technology is obsolete, innovation weak and the workforce disproportionately composed of older workers, as the lack of economic dynamism reduces the hiring rate (Schwerdt, 2011). However, since all workers are dismissed independently of job performance, plant closure reduces the selection bias which arises when firms lay off only their least productive workers.

\footnotetext{
${ }^{1}$ The survey was carried out at the University of Lausanne in collaboration with Patrick McDonald, Fabienne Liechti, Flavia Fossati, Giuliano Bonoli and Daniel Auer.

${ }^{2}$ From the combination of all possible vignettes (5,529,600 unique vignettes per occupation), we drew an orthogonal (d-efficient) sample of 720 vignettes per occupation (Auspurg \& Hinz, 2015). We implemented a D-efficient design that uses an algorithm to minimize inter-correlation among vignette dimensions and interaction terms, while maximizing the variance and balance of the frequency of levels.
}

Our survey covers the workforces of large manufacturing plants that employed no less than 150 employees and that closed down in Switzerland in either 2009 or 2010 . Out of a total of ten plants, we succeeded in getting access to the addresses of the workforce of five plants. In 2011, we sent a questionnaire to all the valid addresses - 90 per cent of the workforce of the five plants - which left us with 1203 displaced workers, both high- and low-tenured ones. 748 individuals responded to the mixed-mode survey (77 percent on paper, 21 on internet and 2 by phone), providing a net response rate of 62 per cent (Baumann, 2016; Oesch \& Baumann, 2015). For both respondents and non-respondents, the survey data was combined, where possible, with information from the unemployment insurance register $(n=357)$ and the firms' administrative data $(n=600)$. The combined dataset provides us with some information on the post-displacement employment status for 887 individuals and with complete wage information on the pre- and post-unemployment job for 387 individuals. The number of observations partly drops because the unemployed and retired cannot declare any post-unemployment wages. Table A3 in the Appendix A shows the descriptive statistics of our analytical sample.

\subsection{Estimation method}

\subsubsection{Factorial survey experiment}

Our dependent variable is the likelihood that a jobseeker is invited to an interview (from 0 to 10 ) and, in a second step, the wage recommendation. Our key independent variable is age, with a fifth each of our fictitious job candidates being attributed 35, 40, 45, 50 and 55 years. Since job candidates applied for three different occupations, occupation and the interaction between occupation and age are the two central control variables. While we also control for gender, nationality, the type of education and type of work experience, the experimental set-up means that these variables are all uncorrelated and do not alter the results.

Our factorial survey has a nested data structure as the same respondent rates up to 12 vignettes. Respondents have different baselines and are likely to compare (and to anchor) the ratings given to successive vignettes with the rating given to the first vignette. We thus estimate a respondent fixed-effects regression that eliminates differences in respondents' individual baselines and only takes into account the within-respondent variance (that is, the differences in a respondent's ratings of the vignettes shown to him or her). We further correct for the clustering of observations within respondents by using clustered standard errors.

\subsubsection{Mass displacement survey}

Our dependent variable is the employment status at the moment of the survey, 1.5-2.5 years after displacement and, in a second step, the change in wages between the pre- and post-unemployment job. For the employment status, we distinguish four outcomes: employed, unemployed, inactive and (early) retired. Our key independent variable is age. We exclude respondents who are younger than 23 (and may be apprentices and often return to formal education) and older than 62 who have only one (women) or two more years before reaching the legal retirement age. Respondents aged 23-62 are regrouped into 5year categories centred around half decades of age: 25 (23-27), 30 (28-32), 35 (33-37) up to 60 (58-62).

We then estimate multinomial logistic regressions on the employment status. Results are shown as the age contrast in being unemployed rather than employed, based on predictive margins. We make sure that age cohorts are comparable by controlling for gender, a proxy for nationality (four categories), education (six levels) and occupations (nine ISCO groups).

Finally, we examine differences in age discrimination across occupations by distinguishing three occupational groups that correspond to three hierarchical levels of skill requirements: (i) upper-level whitecollar employees are high-skilled and include occupations such as 
managers, professionals and associate professionals (ISCO major groups 1-3); (ii) office clerks are mid-skilled and mainly made up by administrative assistants and secretaries (ISCO group 4); (iii) blue-collar workers are low-skilled and include occupations such as craft and production workers as well as elementary occupations (ISCO groups 7-9).

At first glance, this occupational variable may seem an overly coarse measure. However, note that our survey covers the homogeneous workforces of five industrial production plants. This means that we deal with the small variety of occupations that exist in manufacturing sites where the contrast between upper-level white-collar employees, clerks in the back office and rank-and-file workers in production is highly salient (and typically enshrined in collective agreements). An added benefit of this threefold distinction is that it makes the occupational groups of our two surveys comparable: expert-accountants are upperlevel white collar employees, HR assistants are office clerks and building caretakers are blue-collar workers.

\section{The institutional context of Switzerland}

Our study is set in Switzerland, a country traditionally marked by a tight labour market with low unemployment rates and high levels of immigration. Switzerland is comparable to Germany in terms of its occupational labour market and the strong links between firm-based vocational education and employment. However, employment protection is weaker, coverage with collective bargaining lower and there is no legal minimum wage.

Likewise, age discrimination is not explicitly banned by law as in the United States (with the Age Discrimination in Employment Act) or the European Union (with the Employment Equality Framework Directive). Although the Swiss constitution stipulates that "no person may be discriminated against, in particular on grounds of origin, race, gender, age", the federal government has so far refused to introduce an anti-discrimination law that would address the employment relationship (Sonnet, Olsen, \& Manfredi, 2014: 333).

Older workers in Switzerland depend on the labour market for their livelihood until their sixties. While the legal retirement age is lower than in other European countries (64 for women and 65 for men), the welfare state offers few financial incentives to retire early. Combined with a dynamic labour market, this leads to one of the highest employment rates among individuals aged 55-64 in the OECD: 72 per cent in Switzerland as compared to 57 per cent for the European Union and 63 per cent for the United States in $2018 .^{3}$

However, the nexus between low risks of becoming unemployed and high risks of remaining unemployed is also observable for older workers in Switzerland. Fig. 1 shows that the likelihood of having experienced a spell of unemployment over the last 12 months is much higher for young workers in their twenties and early thirties than workers in their forties and, above all, fifties. While this risk exceeds 6 per cent for workers under 25, it is below 2 per cent for workers aged 55 and more. Yet if older workers do lose their job, they face much longer unemployment duration than young jobseekers. While the mean unemployment spell among workers aged 20-29 lasts less than 160 days, it exceeds 210 days among workers aged 50-59.

\section{Results}

\subsection{Invitation to a job interview in the factorial survey experiment}

We first analyse our vignette study and present the likelihood that unemployed workers of different ages get invited to a job interview (see Table 1). Model 1 simply regresses age on the likelihood of getting a job interview and shows that candidates aged 40 and 45 are no less likely to

\footnotetext{
${ }^{3}$ OECD (2019), Employment rate by age group. doi: $10.1787 / 084 f 32 c 7-e n$.
}

get an invitation than the reference category of candidates aged 35 years. However, there is an age penalty for jobseekers aged 50 and, above all, 55. Candidates who are 50 and 55 years old receive ratings that are 0.14 and 0.55 points lower than candidates aged 35 (for a constant of 7.0 points).

Model 2 includes occupations as a control variable. While the size of the age penalty remains unchanged, this model shows that applications for the job of building caretaker were rated more favourably than those for the job of accountant and, above all, HR assistant. The age coefficients change in model 3 when we additionally introduce an interaction between age and occupation. For the reference category of caretakers, the likelihood of being invited to a job interview drops heavily already at the age of 50. In contrast, accountants do not yet experience any age penalty when turning 50 .

Model 4 introduces a set of socio-demographic controls. These variables do not change the age effect, but allow us to compare the effect size for age discrimination with that for discrimination based on nationality. Being 50 (55) years old decreases the likelihood for a caretaker to be invited to a job interview by $0.35(0.54)$ points - and thus exceeds, in terms of disadvantage, the ethnic penalty that candidates of Polish and Turkish origin face relative to native Swiss candidates ( 0.19 or 0.28 points respectively). While it does not help to have a Polish or Turkish name when applying for a job in Switzerland, it is even less advantageous to be over 50 years old.

We provide a clearer picture of the age effect in each occupation by showing the results from model 3 as predictive margins in Fig. 2. It shows that jobseekers aged 40 or 45 are not rated any differently than those aged 35 in any occupation. At age 50, there is a hiring penalty for building caretakers, but not for HR assistants or accountants. However, at age 55, applications for all three occupations receive significantly lower ratings than at the reference age of 35 . The age penalty at 55 is largest for the HR assistant ( -0.80 points) and smallest for the accountant ( -0.36 points).

Finally, we provide a formal test of whether human resources professionals perceive age differently for the three occupations by contrasting the predictive margins by age and occupation (see Fig. A1 in the Appendix A). This analysis shows that the age penalty of being 55 rather than 35 is significantly larger among HR assistants than accountants, but does not vary systematically between HR assistants and caretakers.

\subsection{Reemployment rates in the mass displacement survey}

We turn to the mass displacement survey and show in Fig. 3 how the employment status of displaced workers varies by age two years after plant closure. It is at the age of 35 that the unemployment rate is lowest ( 5 per cent) and the employment rate highest ( 92 per cent). Between the ages of 40-50, the unemployment rate of displaced workers remains stable at 12 per cent. It then increases steeply around 55 and, even more so, around 60, with $28-35$ per cent of displaced workers still unemployed. These are also the ages when early retirement begins to set in, with a modest proportion of 3 per cent around age 55 and 35 per cent around age 60 being able to retire early. Fig. 3 shows that economic inactivity is of minor importance at all ages for our sample of displaced workers, never exceeding 4 per cent.

We estimate a multinomial regression model on the likelihood of different age groups to be unemployed rather than employed, inactive or retired. Since our focus lies on the contrast between being unemployed and employed, we translate these logistic coefficients into predictive margins (see Table W.3 in the web appendix for the full models). A first model only includes, besides age, a dummy variable for pre-displacement firm and confirms that the reference age of 35 is associated with the lowest unemployment risk in our sample of displaced workers. While age groups in their early twenties and thirties are not significantly more likely to be unemployed, displaced workers in their forties have unemployment rates that are $7-8$ percentage points higher 


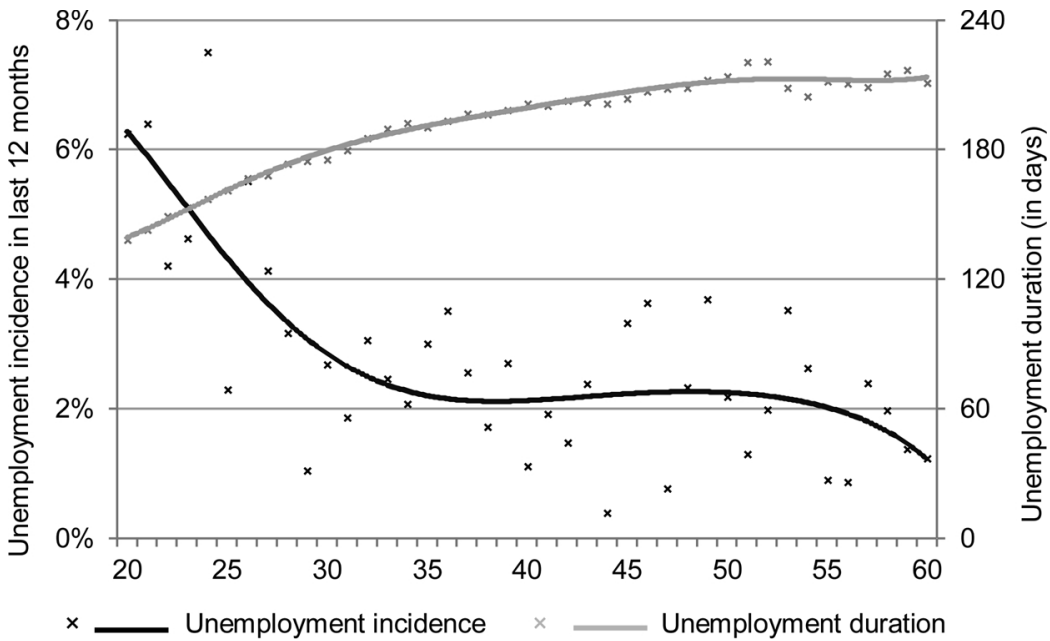

Fig. 1. Unemployment incidence and unemployment duration by age in Switzerland.

Data for unemployment incidence: Swiss sample from European Social Survey, rounds 1-8 (2002-16).

Data for unemployment duration: Swiss unemployment register LAMDA, 2004-12 (see Korber \& Oesch, 2016).

Table 1

The likelihood to get invited to a job interview depending on a candidate's age (respondent fixed-effects regression on a scale from 0 to 10 ).

\begin{tabular}{|c|c|c|c|c|c|}
\hline Dimension & Level & (Model 1) & (Model 2) & (Model 3) & (Model 4) \\
\hline \multirow[t]{5}{*}{$\begin{array}{l}\text { Age } \\
\text { (ref: } 35 \text { years) }\end{array}$} & 40 & $\begin{array}{l}-0.00 \\
(0.07)\end{array}$ & $\begin{array}{l}-0.01 \\
(0.07)\end{array}$ & $\begin{array}{l}0.01 \\
(0.12)\end{array}$ & $\begin{array}{l}0.00 \\
(0.12)\end{array}$ \\
\hline & 45 & -0.03 & -0.05 & -0.01 & -0.01 \\
\hline & & $(0.08)$ & $(0.07)$ & $(0.13)$ & $(0.13)$ \\
\hline & 50 & $\begin{array}{l}-0.14^{*} \\
(0.08)\end{array}$ & $\begin{array}{l}-0.15^{*} \\
(0.08)\end{array}$ & $\begin{array}{l}-0.34^{* * *} \\
(0.13)\end{array}$ & $\begin{array}{l}-0.36^{* * *} \\
(0.13)\end{array}$ \\
\hline & 55 & $\begin{array}{l}-0.55^{* * *} \\
(0.08)\end{array}$ & $\begin{array}{l}-0.57^{* * *} \\
(0.08)\end{array}$ & $\begin{array}{l}-0.54^{* * *} \\
(0.13)\end{array}$ & $\begin{array}{l}-0.54^{* * *} \\
(0.13)\end{array}$ \\
\hline \multirow[t]{2}{*}{$\begin{array}{l}\text { Occupation } \\
\text { (ref: caretaker) }\end{array}$} & Accountant & & $\begin{array}{l}-0.21^{* *} \\
(0.09)\end{array}$ & $\begin{array}{l}-0.33^{* *} \\
(0.14)\end{array}$ & $\begin{array}{l}-0.35^{* *} \\
(0.14)\end{array}$ \\
\hline & HR assistant & & $\begin{array}{l}-1.10^{* * *} \\
(0.10)\end{array}$ & $\begin{array}{l}-1.04^{* * *} \\
(0.14)\end{array}$ & $\begin{array}{l}-1.04^{* * *} \\
(0.14)\end{array}$ \\
\hline \multirow[t]{8}{*}{$\begin{array}{l}\text { Age\#Occupation } \\
\text { (ref: 35\#caretaker) }\end{array}$} & 40\#accountant & & & $\begin{array}{l}0.09 \\
(0.19)\end{array}$ & $\begin{array}{l}0.10 \\
(0.18)\end{array}$ \\
\hline & 40\#HRassist & & & $\begin{array}{l}-0.13 \\
(0.17)\end{array}$ & $\begin{array}{l}-0.12 \\
(0.17)\end{array}$ \\
\hline & 45\#accountant & & & $\begin{array}{l}0.01 \\
(0.18)\end{array}$ & $\begin{array}{l}0.02 \\
(0.18)\end{array}$ \\
\hline & 45\#HRassist & & & $\begin{array}{l}-0.14 \\
(0.18)\end{array}$ & $\begin{array}{l}-0.15 \\
(0.18)\end{array}$ \\
\hline & 50\#accountant & & & $\begin{array}{l}0.34^{*} \\
(0.19)\end{array}$ & $\begin{array}{l}0.36^{*} \\
(0.19)\end{array}$ \\
\hline & 50\#HRassist & & & $\begin{array}{l}0.24 \\
(0.18)\end{array}$ & $\begin{array}{l}0.25 \\
(0.18)\end{array}$ \\
\hline & 55\#accountant & & & $\begin{array}{l}0.18 \\
(0.18)\end{array}$ & $\begin{array}{l}0.19 \\
(0.18)\end{array}$ \\
\hline & 55\#HRassist & & & $\begin{array}{l}-0.26 \\
(0.19)\end{array}$ & $\begin{array}{l}-0.25 \\
(0.18)\end{array}$ \\
\hline \multirow[t]{4}{*}{$\begin{array}{l}\text { Nationality } \\
\text { (ref: Swiss) }\end{array}$} & Spanish & & & & $\begin{array}{l}-0.04 \\
(0.06)\end{array}$ \\
\hline & Polish & & & & $\begin{array}{l}-0.19^{* * *} \\
(0.06)\end{array}$ \\
\hline & Turkish & & & & $\begin{array}{l}-0.28^{* * *} \\
(0.07)\end{array}$ \\
\hline & Constant & $\begin{array}{l}7.00^{* * *} \\
(0.05)\end{array}$ & $\begin{array}{l}7.45^{* * *} \\
(0.07)\end{array}$ & $\begin{array}{l}7.47^{* * *} \\
(0.10)\end{array}$ & $\begin{array}{l}7.54^{* * \cdots} \\
(0.12)\end{array}$ \\
\hline \multirow[t]{4}{*}{ Additional controls } & & No & No & No & Yes \\
\hline & $\mathrm{N}$ vignettes & 5,290 & 5,290 & 5,290 & 5,290 \\
\hline & $\mathrm{N}$ respondents & 501 & 501 & 501 & 501 \\
\hline & $\mathrm{R} 2$ & 0.02 & 0.10 & 0.10 & 0.10 \\
\hline
\end{tabular}

Robust standard errors in parentheses.

Additional controls include gender, type of education and type of experience. For the full model 4 with all controls, see Table W.2 in the web-appendix.

$* * * \mathrm{p}<0.01$.

$* * \mathrm{p}<0.05$.

$* \mathrm{p}<0.1$. 


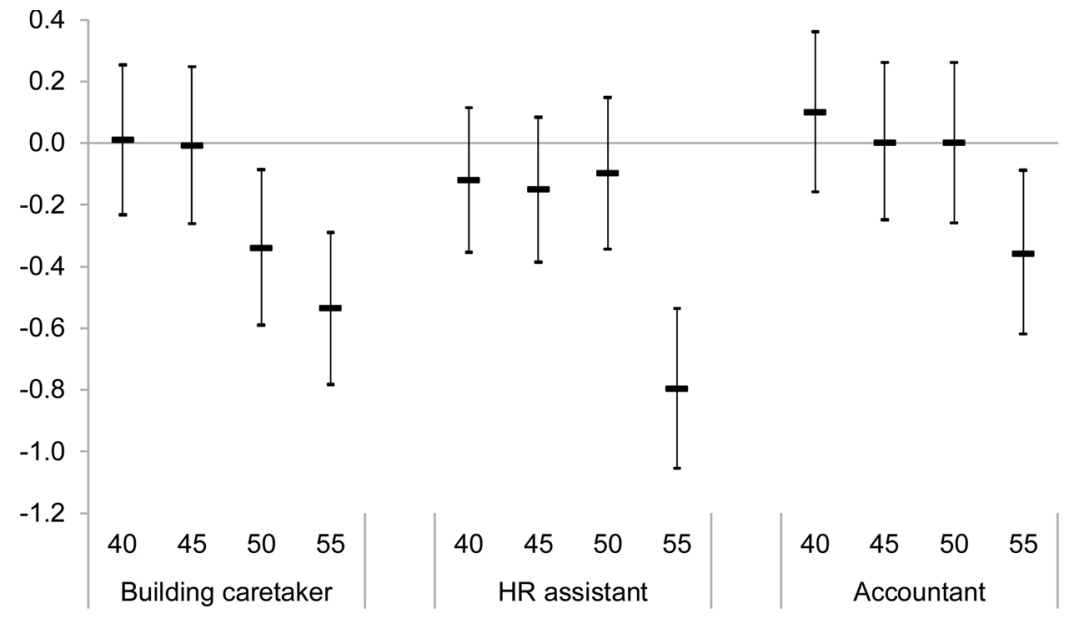

Fig. 2. the likelihood to get invited to a job interview by age - relative to candidates aged 35 (predictive margins on a scale from 0 to 10 ).

The graph shows the predictive margins and $95 \%$ confidence intervals of a respondent fixed-effects regression on the likelihood to get invited for a job interview (based on model 3).

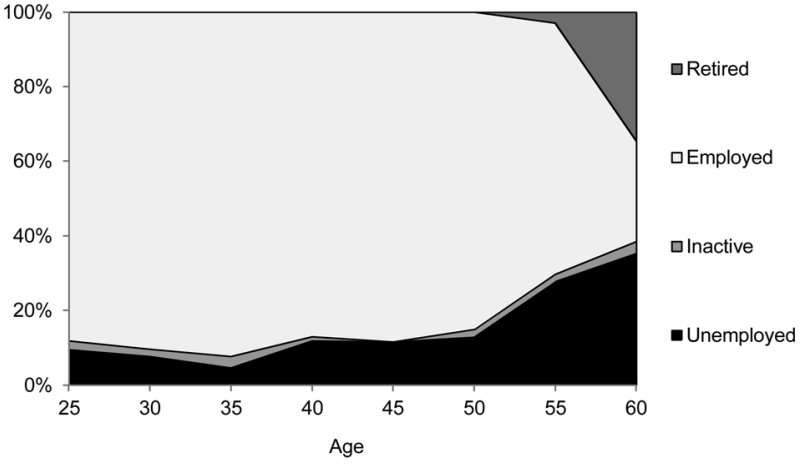

Fig. 3. employment status two years after mass displacement by age (age at displacement).

N (observations): 786.

Note: age is measured in age bands (age 25 includes 23-27, age 30 includes $28-32$, age 35 includes $33-37$ etc.).

than those of former colleagues aged 35 . However, the real contrast is with ages 55 and 60 where the likelihood of being unemployed exceeds that of displaced workers aged 35 by $20-30$ percentage points. Adding a set of socio-demographic controls does not reduce the age differences in unemployment among displaced workers (see model 2). If anything, the age differences become somewhat larger (Table 2).

We examine again whether age differences in unemployment vary by occupation and contrast in Fig. 4 the predictive margins by age and occupation. These results show that the unemployment risks differ much more between middle-aged and older clerks as well as between middle-aged and older blue collar workers than between middle-aged and older white-collar employees. In other words, the unemployment rates for ages 55 and 60 relative to 35 are much higher among clerks and blue-collar workers than among white-collar employees. In our sample of displaced workers, upper-level white-collar employees are clearly better insulated against long-term unemployment when they reach their mid-fifties than clerks and blue-collar workers.
Table 2

The likelihood of displaced workers to be unemployed rather than employed two years after plant closure (predictive margins of multinomial regression on employment status).

\begin{tabular}{llll}
\hline & & (Model 1) & (Model 2) \\
\hline $\begin{array}{l}\text { Age } \\
\text { (ref: 35 years) }\end{array}$ & 25 & 0.07 & 0.06 \\
& & $(0.06)$ & $(0.05)$ \\
& 30 & 0.05 & 0.05 \\
& & $(0.05)$ & $(0.05)$ \\
& 40 & $0.08^{*}$ & $0.08^{* *}$ \\
& & $(0.04)$ & $(0.04)$ \\
& 45 & $0.07^{*}$ & $0.07^{* *}$ \\
& & $(0.04)$ & $(0.03)$ \\
& 50 & $0.08^{* *}$ & $0.09^{* * *}$ \\
& & $(0.04)$ & $(0.04)$ \\
& 55 & $0.21^{* * *}$ & $0.22^{* * *}$ \\
Socio-demographic controls & & $(0.05)$ & $(0.05)$ \\
N respondents & 60 & $0.30^{* * *}$ & $0.34^{* * *}$ \\
Pseudo R2 & & $(0.04)$ & $(0.04)$ \\
& & & \\
& & No & Yes \\
& & 776 & 776 \\
\hline
\end{tabular}

Standard errors in parentheses.

See note below Fig. 3. Both models control for pre-displacement firm. Additional controls in model 2 include sex, education, occupation and proxy for nationality (see Table W.3 in the web-appendix).

$* * * \mathrm{p}<0.01$.

$\because * \mathrm{p}<0.05$.

$* \mathrm{p}<0.1$.

\subsection{Variation of wages across age groups}

In a last set of analyses, we integrate information on wages in order to test the expectation that older workers are considered too costly. We first look at the factorial survey and the wages that recruiters indicated for each profile if a given candidate were to be employed full-time. Fig. 5 shows that the wages deemed adequate for a given profile increase with age. Older candidates receive wage recommendations that 


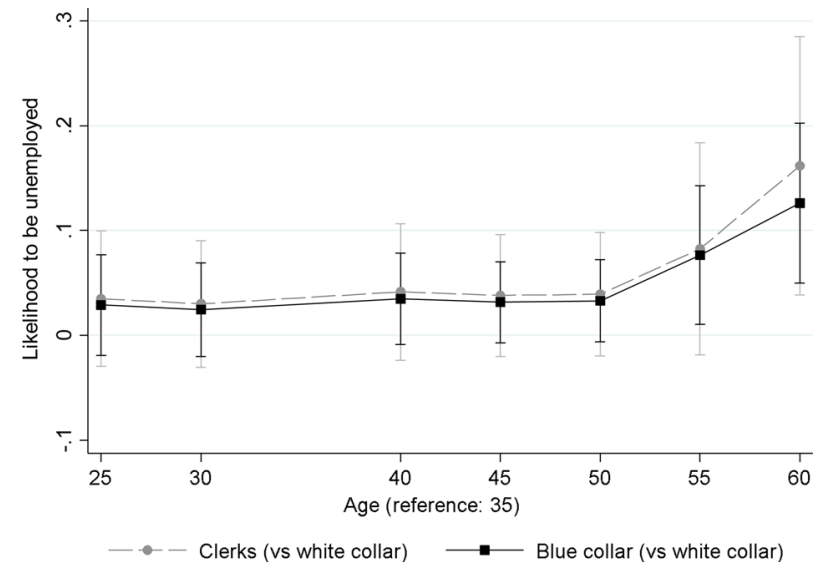

Fig. 4. Difference in the likelihood to be unemployed between occupational groups for a given age (contrast of predictive margins, $95 \%$ confidence intervals).

$\mathrm{N}$ (observations): 786.

Note: age is measured in age bands (age 25 includes 23-27, age 30 includes 28-32, age 35 includes 33-37 etc.).

White collar occupations include managers, professionals and technicians (ISCO1, 2, 3) and blue collar occupations craft workers, machine operators and elementary occupations (ISCO7, 8, 9).

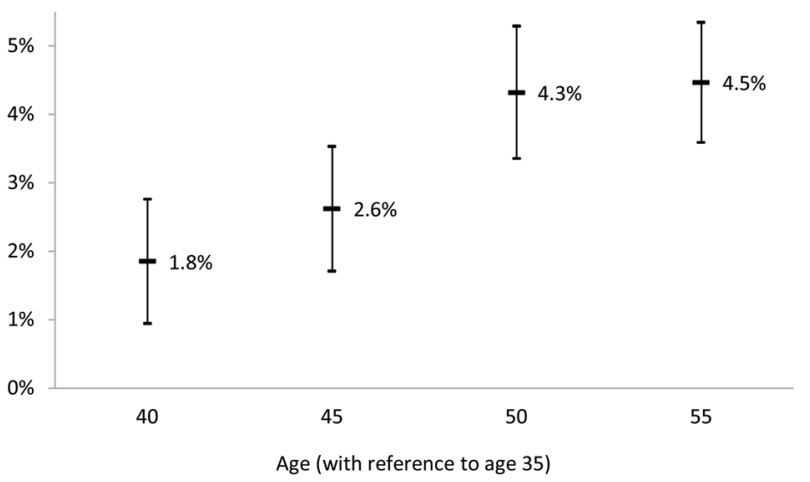

Fig. 5. Wage recommendation made by recruiters depending on fictional candidates' age.

The graph shows the coefficients and $95 \%$ confidence intervals of a respondent fixed-effects linear regression on the logarithm of the wage recommendations for job candidates by age. See Table W. 3 in the web-appendix for the regression table.

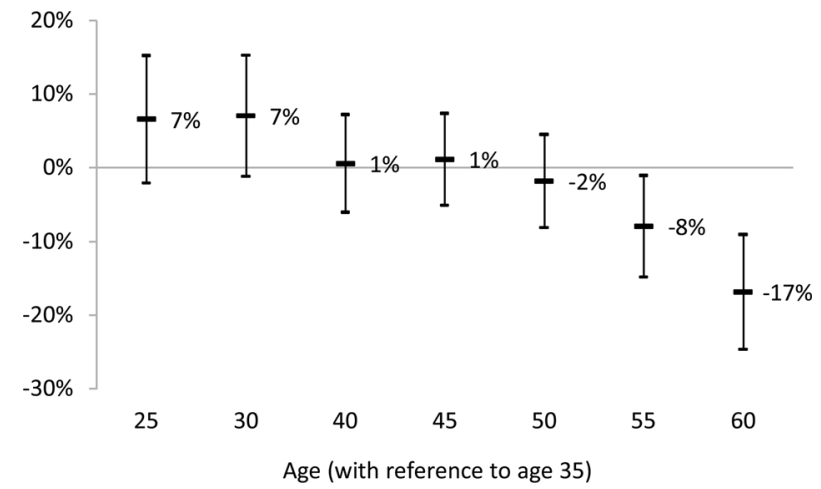

Fig. 6. Wage difference in post-unemployment relative to pre-unemployment job. The graph shows the coefficient and $95 \%$ confidence intervals of a linear regression on change in hourly wages with controls for sex, education, occupation, proxy for nationality and pre-displacement firm. See Table W.5 in the web-appendix for the regression table. exceed those of candidates aged 35 by 1.8 percent at age $40,2.6$ percent at $45,4.3$ percent at 50 and 4.5 percent at 55 . Translated into annual earnings, this means that for the same productive attributes, workers aged 50 and 55 are considered to deserve half a monthly wage more per year than workers in their mid-thirties - with no systematic differences across the three occupations (interaction effects are not statistically significant).

We thus find the seemingly paradoxical result that recruiters value older workers more highly in terms of the recommended wage, all the while being less likely to invite them to a job interview. This is consistent with our third hypothesis and the argument that older workers are sorted out in the hiring process because they are considered too expensive - and they are considered too expensive because recruiters expect jobseekers' going wage to rise with age.

We further examine this hypothesis with the mass displacement survey and run a regression on change in hourly wages between the preand post-displacement job (see Fig. 6). The reference group of workers aged 35 succeeded in maintaining, on average, the same level of earnings. Consistent with ascending early careers, younger individuals aged around 25-30 even increased their earnings in the post-displacement job. While workers between ages 40 and 50 did not have to accept wage cuts, this was the case for older workers. Workers aged around 55 and 60 who succeeded to find a new position earned in their post-displacement job between 8 (age 55) and 17 percent (age 60) less than in their pre-displacement job. Translated in annual earnings, this means that older workers secured a new job at the cost of receiving one to two monthly wages less per year. This finding is again consistent with our third hypothesis that expected employers to be reluctant to hire older jobseekers - unless these latter are willing to make substantial wage sacrifices.

\section{Discussion and conclusion}

Regardless of whether we focus on the factorial survey experiment among recruiters or on the natural experiment among displaced workers, we find large age differences in access to jobs in the Swiss labour market. In the first research design, older jobseekers do not vary from younger jobseekers in their productive attributes and in the second design they were laid off by the same exogenous event as their younger colleagues, namely plant closure.

In both of these quasi-experimental settings, the likelihood to be invited to a job talk or to be reemployed decreases by age. Our analysis thus provides support for the argument of heterogeneous age effects of unemployment. The greater vulnerability of older workers to the consequences of unemployment is not primarily explained by selection. Both experiments suggest that age in and by itself causally affects the chances of finding a job for unemployed workers in Switzerland.

Our reference category of 35 coincides with the highpoint of employability, when workers have acquired 10-15 years of work experience. There is not much of an age barrier for jobseekers in their late forties who do not face very different job prospects than those aged 35 . The age penalty surfaces around the age of 50 and then becomes sizeable at ages 55 and 60 .

What are the reasons that explain the age penalty in hiring? Our first hypothesis argued that employers expect older workers to underperform in tasks requiring physical skills such as speed and endurance. As a consequence, the age barrier in hiring should be larger in blue-collar than white-collar occupations. This expectation is partly borne out by our data. Both surveys show a larger age penalty for blue-collar workers than upper-level white-collar employees. However, office clerks are not in a better position than blue-collar workers, although their job makes lower demands on physical performance than is the case for blue-collar workers. Older jobseekers may thus struggle to get reemployed in 
occupations dominated by routine tasks more generally.

Our results allow us to reject our second hypothesis that expected the age penalty to be rooted in employers' concern about promoting internal careers (Daniel \& Heywood, 2007). If this were the case, the age barrier to hiring should be higher among managers and professionals than office clerks and blue-collar workers. However, blue-collar workers and office clerks suffer larger age penalties than upper-level white-collar employees, even though internal labour markets and delayed compensation schemes play a subordinate role in their careers. Upper-level white collar employees seem better shielded from age discrimination overall: the age penalty sets in later (around 55 rather than 50) and is smaller.

Finally, our third hypothesis argued that employers expect older workers to cost too much relative to their productivity. Therefore, recruiters would hire older jobseekers only if they accepted large wage cuts. Our data provide support for the two underlying assumptions of this hypothesis. On the demand-side of the labour market, our factorial survey shows that recruiters indicate higher reference wages for older than younger jobseekers - even though their productive characteristics do not vary. On the supply-side of the labour market, our data suggest that displaced workers in their mid-fifties only find new jobs at the cost of much lower wages than what they earned in their pre-displacement job.

Our results allow us to rule out the internal career thesis as the main mechanism behind the age barrier in hiring. However, other explanations than our two hypotheses on physical demands and wage costs are also consistent with our findings, notably a taste-based account of discrimination. If recruiters hold age-based stereotypes and dislike hiring older workers, these latter may need to compensate their disadvantage by offering skills that are in short supply, notably long experience and specialized expertise. Where these latter skills are crucial, typically in management and the professions, older workers may stand a better chance of getting reemployed than in the less specialized positions on the factory floor and in the back office. Likewise, our finding that older workers trade in lower wages against the opportunity of getting a new job could also be explained with taste-based discrimination. The idea is that older workers need to offer large discounts on their wages to be considered attractive candidates for a job.

While our data do not allow us to quantify the role of stereotypes, they throw doubt on accounts that primarily emphasize rational decision-making by human resources departments. One such account is that older jobseekers are discarded because they have only a limited number of years to go until retirement - which makes their recruitment expensive, given the fixed costs created by searching, training and job vacancies. Both our surveys show a large hiring disadvantage at the age of 55 when workers have another 9-10 years to go until retirement. Given that median job tenure is less than seven years in Europe (Eurofound, 2015: 17) and less than five years in the United States, (Bureau of Labor Statistics, 2019) rational recruiters should consider a horizon of 9-10 years as sufficient to recoup investment. This should notably be the case in more routine occupations where search costs are lower and workers expected to hit the ground running such as in production work, building caretaking or the back office. Yet our data show that it is precisely in these occupations that the age handicap is largest.

Finally, our findings raise an uncomfortable question for social policy. Unemployed workers in their mid-fifties have a much harder time in the recruitment process than younger candidates. Yet, they have a decade more to go until they reach the legal retirement age. The prolonged unemployment at the end of people's careers not only leads to much mental suffering and unhappiness (Lassus et al., 2015), but also points to an unresolved tension in the reform of pension systems. As long as employers are reluctant to hire older workers, the government summons to work longer sounds hollow to older jobseekers incapable of securing new employment.

\section{Acknowledgements}

This research was led within two projects: CRITEVENTS (Critical Life Events and the Dynamics of Inequality), financed by the NORFACE network, and NCCR LIVES (Overcoming Vulnerability: Life course perspectives), financed by the Swiss National Science Foundation. We are grateful for the financial support and would like to thank Isabel Baumann for the joint collection of the mass displacement survey and Patrick McDonald, Fabienne Liechti, Flavia Fossati, Giuliano Bonoli and Daniel Auer for the joint development of the factorial survey experiment. This article greatly benefitted from the comments by Katrin Auspurg, Erzsébet Bukodi, Josef Brüderl, Alessandro Di Nallo, Maïlys Korber, Patrick McDonald, two anonymous reviewers and the editor Carlo Barone.

\section{Appendix A}

Table A1

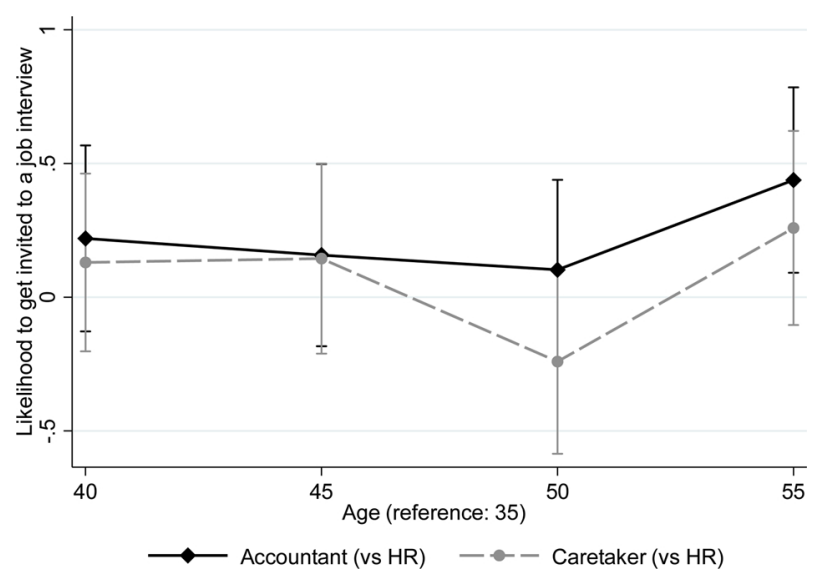

Fig. A1. Difference in likelihood to get invited to an interview between occupations for a given age (contrast of predictive margins, $95 \%$ confidence intervals). 
Table A1

Variables included in the vignettes of the factorial survey experiment.

\begin{tabular}{|c|c|}
\hline Dimension (variable) & Levels (values) \\
\hline Gender* & Male, female \\
\hline Age & $35,40,45,50,55$ \\
\hline Children & $0,1,2,3$ \\
\hline Civil Status & Single, married, divorced \\
\hline Type of education & Vocational, general \\
\hline Type of work Experience & Private sector, public sector \\
\hline Nationality* & Swiss, Spanish, Turkish, Polish \\
\hline \multirow[t]{2}{*}{ Mother tongue } & German/French \\
\hline & German/French plus an additional language \\
\hline Participation in active labour market program ${ }^{* *}$ & None, training program, occupational program (matched and unmatched), subsidy, temporary employment \\
\hline Channel of Application & Advertisement, referral from current employee, unsolicited application, regional employment service \\
\hline Hobby** & None, swim coaching, board member of a Swiss/foreign cultural association, volunteer for Red Cross driving service \\
\hline
\end{tabular}

* These dimensions were denoted by the names of applicants.

$* *$ "None" implies that this dimension did not appear in the vignette.

Table A2

Example of a vignette (translated from French and German).

You will now be asked to evaluate 12 fictional candidates for 3 different jobs. For each candidate, please give the likelihood that you would invite him or her to a job interview $(0=$ very unlikely, $10=$ very likely) as well as the monthly salary you would pay them. All the candidates completed their compulsory schooling in Switzerland, have been unemployed for 6 months, and lost their previous job due to the closure of their firm.

$\underline{\text { HR assistant job candidate: }}$

Application: $\quad$ One of your employees had recommended Mr Ismail Üstgül for the

Personal details: vacant position.

Education: He is 45 years old, has 2 school-aged children and is unmarried.

Professional experience:

He has completed upper-secondary vocational education

Language skills:

He has, amongst other work experience, 8 years of Human Resources experience in the private sector.

Hobby: Mr Üstgül speaks French and Turkish.

Further information: He is a committee member of Türkgücü, a Turkish cultural association.

He is currently completing training in human resources management, paid for by the Regional Employment Office.

\begin{tabular}{|c|c|}
\hline Invite for an interview: & Monthly gross salary (100\%): \\
\hline O0 0 01 O2 O3 O4 O5 O6 O7 O8 O9 O10 & CHF \\
\hline
\end{tabular}

\section{$\underline{\text { Accountant job candidate: }}$}

Application:

Personal details:

Education:

Professional experience:

Language skills:
A few days ago, you received a spontaneous application from Ms Nathalie Rochat.

She is 40 years old, has one school-aged child, and is divorced.

She completed a federal diploma of vocational education and training as a commercial employee as well as an advanced federal diploma of higher education as chartered expert in financial and managerial accounting

She has, amongst other work experience, 8 years of experience as accountant in the public sector.

Ms Rochat speaks French

\begin{tabular}{|c|c|}
\hline Invite for an interview: & Monthly gross salary (100\%): \\
\hline $\mathbf{0} 0 \mathbf{0 1 0} \mathbf{0} \mathbf{0} 3 \mathbf{0} 040506070809010$ & CHF \\
\hline
\end{tabular}


Table A2 (continued)

Building caretaker job candidate:

Application: $\quad$ The Regional Unemployment Office has sent you the application of $\mathrm{Mr}$ Pedro Martinez.

Personal details: $\quad$ He is 45 years old, has no children and is married.

Education: $\quad$ He completed an apprenticeship as a commercial building maintenance specialist.

Professional experience: $\quad$ He has, amongst other work experience, 8 years of building maintenance experience in the private sector.

Language skills: $\quad$ Mr Martinez speaks German and Spanish.

Hobby:

In his free time, he volunteers as a driver for the Red Cross.

Further information: $\quad$ Alongside his job search, he has a part-time job as a sales assistant in a retail business.

\begin{tabular}{|c|c|}
\hline Invite for an interview: & Monthly gross salary (100\%): \\
\hline $\mathbf{0} 0010203040506070809010$ & CHF \\
\hline
\end{tabular}

Table A3

Mass displacement survey - descriptive statistics of the variables used.

\begin{tabular}{|c|c|c|c|}
\hline & $\min$ & $\max$ & mean \\
\hline \multicolumn{4}{|l|}{ Employment status } \\
\hline Gainfully employed & 0 & 1 & 0.73 \\
\hline Unemployed & 0 & 1 & 0.18 \\
\hline Early retired & 0 & 1 & 0.07 \\
\hline Economically inactive & 0 & 1 & 0.02 \\
\hline Change in post- relative to pre-unemployment wage & -0.63 & 0.67 & -0.04 \\
\hline Age at moment of displacement & 23 & 62 & 46.72 \\
\hline $25(22-27)$ & 0 & 1 & 0.06 \\
\hline $30(28-32)$ & 0 & 1 & 0.07 \\
\hline $35(33-37)$ & 0 & 1 & 0.08 \\
\hline $40(38-42)$ & 0 & 1 & 0.12 \\
\hline $45(43-47)$ & 0 & 1 & 0.16 \\
\hline $50(48-52)$ & 0 & 1 & 0.19 \\
\hline $55(53-57)$ & 0 & 1 & 0.13 \\
\hline $60(58-62)$ & 0 & 1 & 0.20 \\
\hline Male & 0 & 1 & 0.83 \\
\hline \multicolumn{4}{|l|}{ Nationality (proxy) } \\
\hline Swiss, German, French & 0 & 1 & 0.70 \\
\hline Italy & 0 & 1 & 0.08 \\
\hline Spain, Portugal & 0 & 1 & 0.03 \\
\hline Other & 0 & 1 & 0.18 \\
\hline \multicolumn{4}{|l|}{ Education } \\
\hline Does not know & 0 & 1 & 0.03 \\
\hline Compulsory education & 0 & 1 & 0.14 \\
\hline Pre-apprenticeship & 0 & 1 & 0.03 \\
\hline Upper secondary education & 0 & 1 & 0.54 \\
\hline Higher vocational education & 0 & 1 & 0.15 \\
\hline University & 0 & 1 & 0.11 \\
\hline \multicolumn{4}{|l|}{ Occupation (isco-1digit) } \\
\hline Managers (isco1) & 0 & 1 & 0.09 \\
\hline Professionals (isco2) & 0 & 1 & 0.05 \\
\hline Technicians and associate professionals (isco3) & 0 & 1 & 0.20 \\
\hline Clerks (isco4) & 0 & 1 & 0.08 \\
\hline Craft workers (isco7) & 0 & 1 & 0.26 \\
\hline Plant operators (isco8) & 0 & 1 & 0.29 \\
\hline Elementary occupations (isco9) & 0 & 1 & 0.04 \\
\hline
\end{tabular}

Mass displacement survey 2011. N observations: 776. 


\section{Appendix B. Supplementary data}

Supplementary material related to this article can be found, in the online version, at doi:https://doi.org/10.1016/j.rssm.2019.100441.

\section{References}

Auspurg, K., Hinz, T., \& Sauer, C. (2017). Why should women get less? Evidence on the gender pay gap from multifactorial survey experiments. American Sociological Review, 82(1), 179-210.

Auspurg, K., \& Hinz, T. (2015). Factorial survey experiments, quantitative applications in the social sciences. Los Angeles: Sage.

Baert, S., Norga, J., Thuy, Y., \& Van Hecke, M. (2016). Getting grey hairs in the labour market. An alternative experiment on age discrimination. Journal of Economic Psychology, 57, 86-101.

Baert, S. (2018). Hiring discrimination: An overview of (almost) all correspondence experiments since 2005. In S. M. Gaddis (Ed.). Audit studies: Behind the scenes with theory, method, and nuance (pp. 63-77). Cham: Springer.

Baumann, I. (2016). The plight of older workers. Cham: Springer.

Brand, J. E. (2015). The far-reaching impact of job loss and unemployment. Annual Review of Sociology, 41, 359-375.

Brand, J. E., \& Xie, Y. (2010). Who benefits most from college? Evidence for negative selection in heterogeneous economic returns to higher education. American Sociological Review, 75(2), 273-302.

Breen, R., Choi, S., \& Holm, A. (2015). Heterogeneous causal effects and sample selection bias. Sociological Science, 2, 351-369.

Bureau of Labor Statistics (2019). Employee tenure. www.bls.gov/news.release/tenure.toc. htm.

Büsch, V., Dahl, S. A., \& Dittrich, D. A. (2009). An empirical study of age discrimination in Norway and Germany. Applied Economics, 41(5), 633-651.

Chan, S., \& Stevens, A. H. (2001). Job loss and employment patterns of older workers. Journal of Labor Economics, 19(2), 484-521.

Daniel, K., \& Heywood, J. S. (2007). The determinants of hiring older workers: UK evidence. Labour Economics, 14(1), 35-51.

Eurofound (2015). Job tenure in turbulent times. Luxembourg: Publications Office of the European Union.

Farber, H. S. (1999). Mobility and stability: The dynamics of job change in labor markets. Handbook of Labor Economics, 3, 2439-2483.

Farber, H. S. (2017). Employment, hours, and earnings consequences of job loss: US evidence from the displaced workers survey. Journal of Labor Economics, 35(1), 235-272.

Farber, H. S., Silverman, D., \& Von Wachter, T. M. (2017). Factors determining callbacks to job applications by the unemployed: An audit study. RSF: Russell Sage Foundation Journal of the Social Sciences, 3(3), 168-201.

Heisig, J. P., \& Radl, J. (2017). Adding scars to wrinkles? Long-run effects of late-career job loss on retirement behavior and personal income. Work, Aging and Retirement, 3(3), 257-272.

Henkens, K., van Solinge, H., \& Cozijnsen, R. (2009). Let go or retain? A comparative study of the attitudes of business students and managers about the retirement of older workers. Journal of Applied Social Psychology, 39(7), 1562-1588.

Hirsch, B. T., Macpherson, D. A., \& Hardy, M. A. (2000). Occupational age structure and access for older workers. Industrial and Labor Relations Review, 53(3), 401-418.

Homrighausen, P., \& Wolf, K. (2018). Wiederbeschäftigungschancen Älterer: Wo Vermittlungsfachkräfte Handlungsbedarf sehen. IAB-Kurzbericht 11/2018.

Hornstein, A., \& Lubik, T. (2015). The rise in long-term unemployment: Potential causes and implications. Economic Quarterly, 2, 125-149.

Gangl, M. (2006). Scar effects of unemployment: An assessment of institutional complementarities. American Sociological Review, 71(6), 986-1013.

Jolkkonen, A., Koistinen, P., \& Kurvinen, A. (2012). Re-employment of displaced workers-The case of a plant closing on a remote region in Finland. Nordic Journal of Working Life Studies, 2(1), 81-100.
Karpinska, K., Henkens, K., \& Schippers, J. (2011). The recruitment of early retirees: A vignette study of the factors that affect managers' decisions. Ageing and Society, 31(4), 570-589.

Karpinska, K., Henkens, K., \& Schippers, J. (2013). Retention of older workers: Impact of managers' age norms and stereotypes. European Sociological Review, 29(6), 1323-1335.

Knuth, M., \& Kalina, T. (2002). Early exit from the labour force between exclusion and privilege: Unemployment as a transition from employment to retirement in West Germany. European Societies, 4(4), 393-418.

Korber, M., \& Oesch, D. (2016). L'évolution de l'emploi, du chômage et du PIB dans le canton de Vaud depuis 1990. Une étude comparative avec la Suisse, LIVES Working Paper 51. University of Lausanne.

Lahey, J. N. (2008). Age, women, and hiring: An experimental study. Journal of Human Resources, 43(1), 30-56.

Lassus, L. A. P., Lopez, S., \& Roscigno, V. J. (2015). Aging workers and the experience of job loss. Research in Social Stratification and Mobility, 41, 81-91.

McDonald, P. (2019). How factorial survey analysis improves our understanding of employer preferences. Swiss Journal of Sociology, 45(2), 237-260.

Mulders, J., van Dalen, H., Henkens, K., \& Schippers, J. (2014). How likely are employers to rehire older workers after mandatory retirement? A vignette study among managers. De Economist, 162, 415-431.

Murphy, E., \& Oesch, D. (2018). Is employment polarisation inevitable? Occupational change in Ireland and Switzerland, 1970-2010. Work, Employment and Society, 32(6), 1099-1117.

Neumark, D. (2018). Experimental research labor market discrimination. Journal of Economic Literature, 56(3), 799-866.

Neumark, D., Burn, I., \& Button, P. (2015). Is it harder for older workers to find jobs? New and improved evidence from a field experiment, NBER working paper series 21669.

Ng, T. W., \& Feldman, D. C. (2008). The relationship of age to ten dimensions of job performance. Journal of Applied Psychology, 93(2), 392.

Oesch, D., \& Baumann, I. (2015). Smooth transition or permanent exit? Evidence on job prospects of displaced industrial workers. Socio-Economic Review, 13(1), 101-123.

Pager, D., \& Quillian, L. (2005). Walking the talk? What employers say versus what they do. American Sociological Review, 70(3), 355-380.

Radl, J. (2012). Too old to work, or too young to retire? The pervasiveness of age norms in Western Europe. Work, Employment and Society, 26(5), 755-771.

Riach, P. A. (2015). A field experiment investigating age discrimination in four European labour markets. International Review of Applied Economics, 29(5), 608-619.

Rosen, B., \& Jerdee, T. H. (1976). The nature of job-related age stereotypes. Journal of Applied Psychology, 61(2), 180.

Schwerdt, G. (2011). Labor turnover before plant closure: "Leaving the sinking ship" vs. "Captain throwing ballast overboard". Labour Economics, 18(1), 93-101.

Skirbekk, V. (2008). Age and productivity capacity: Descriptions, causes and policy options. Ageing Horizons, 8, 4-12.

Sonnet, A., Olsen, H., \& Manfredi, T. (2014). Towards more inclusive ageing and employment policies: The lessons from France, the Netherlands, Norway and Switzerland. De Economist, 162(4), 315-339.

Wallander, L. (2009). 25 years of factorial surveys in sociology: A review. Social Science Research, 38(3), 505-520.

Warr, P. (1995). Age and job performance. In J. Snel, \& R. Cremer (Eds.). Work and aging: A European prospective (pp. 309-322). London: Taylor and Francis.

Weiss, E. M., \& Maurer, T. (2004). Age discrimination in personnel decisions: A reexamination. Journal of Applied Social Psychology, 34(8), 1551-1562.

Xie, Y., Brand, J. E., \& Jann, B. (2012). Estimating heterogeneous treatment effects with observational data. Sociological Methodology, 42(1), 314-347. 